See discussions, stats, and author profiles for this publication at: https://www.researchgate.net/publication/311854689

\title{
Feed efficiency and enteric methane production of Nellore cattle in the feedlot and on pasture
}

Article in Animal Production Science · January 2016

DOI: 10.1071/AN16303

CITATION

1

7 authors, including:

ana claudia Ruggieri

São Paulo State University

129 PUBLICATIONS 540 CITATIONS

SEE PROFILE

Maria Eugenia Zerlotti Mercadante

Instituto de Zootecnia

147 PUBLICATIONS 1,109 CITATIONS

SEE PROFILE
READS

69

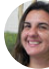

Renata Helena Branco

Secretaria de Agricultura e Abastecimento do Estado de São Paulo 71 PUBLICATIONS 418 CITATIONS

SEE PROFILE

Some of the authors of this publication are also working on these related projects:

Verificação do efeito mitigador de gases de efeito estufa pelo manejo de pastagens com fertilizante nitrogenado ou em consórcio com leguminosas forrageiras View project

SORGO-SUDÃO: ESTRATÉGIA DE MANEJO ALIMENTAR NO OUTONO-INVERNO PARA PRODUÇÃO DE LEITE View project 


\title{
Feed efficiency and enteric methane production of Nellore cattle in the feedlot and on pasture
}

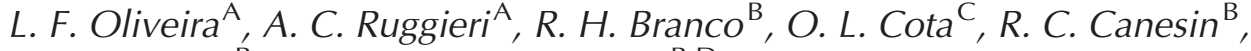 \\ H. J. U. Costa ${ }^{\mathrm{B}}$ and M. E. Z. Mercadante ${ }^{\mathrm{B}, \mathrm{D}}$ \\ ADepartamento de Zootecnia, Universidade Estadual Paulista 'Júlio de Mesquita Filho', Faculdade de Ciências \\ Agrárias e Veterinárias, Via de Acesso Professor Paulo Donato Castellane, 14884-900, Jaboticabal, SP, Brazil. \\ B Instituto de Zootecnia, Centro Avançado de Pesquisa Tecnológica do Agronegócio de Bovinos de Corte, \\ Rodovia Carlos Tonanni, km 94, 14.174-000, Sertãozinho, SP, Brazil. \\ ${ }^{\mathrm{C}}$ Departamento de Zootecnia, Universidade Federal dos Vales do Jequitinhonha e Mucuri, campus JK, \\ Alto do Jacuba, Rodovia MGT 367, km 587, 5000, Diamantina, MG, Brazil. \\ ${ }^{D}$ Corresponding author. Email: mercadante@iz.sp.gov.br
}

\begin{abstract}
The objective of the present study was to assess the relationship between residual feed intake (RFI) evaluated in a feedlot-performance test and on pasture, and to determine the effect of feedlot RFI classification on enteric methane $\left(\mathrm{CH}_{4}\right)$ production in the feedlot and on pasture. Seventy-three animals (25 with a low RFI, 24 with a medium RFI and 24 with a high RFI) classified in a feedlot performance test were subjected to performance testing on Brachiaria brizantha cv. Marandu pasture. Enteric $\mathrm{CH}_{4}$ was measured in a sample of these animals ( $n=47$, with high and low RFI) by the sulfur hexafluoride tracer-gas technique after the feedlot-performance test and during the performance test on pasture. In the feedlot-performance test, dry-matter intake (DMI) of low-RFI animals was $9.4 \%$ and $19.7 \%$ lower $(P<0.05)$ than that of medium- and high-RFI animals respectively. However, there was no difference in DMI and, consequently, in RFI on pasture among animals classified as low, medium and high RFI. Accordingly, there is evidence of re-ranking of animals for RFI performance tested in the feedlot after weaning and, subsequently, on pasture. During the period of enteric $\mathrm{CH}_{4}$ measurement in the feedlot and on pasture, the DMI, neutral detergent-fibre intake and gross-energy intake of low-RFI animals were lower than those of highRFI animals, and low-RFI animals exhibited greater DM and neutral detergent fibre digestibility only in the feedlot. Enteric $\mathrm{CH}_{4}$ production did not differ between low- and high-RFI animals either in the feedlot (101 and $107 \mathrm{~g} \mathrm{CH}_{4} /$ day) or on pasture (101 and $95.9 \mathrm{~g} \mathrm{CH}_{4} /$ day). A significant difference in $\mathrm{CH}_{4}$ yield $\left(\mathrm{CH}_{4} / \mathrm{kg} \mathrm{DMI}\right)$ was observed on pasture between animals with low and high RFI (17.6 and $13.7 \mathrm{~g} \mathrm{CH}_{4} / \mathrm{kg}$ DMI respectively). The results did not support the hypothesis that an increase in feed efficiency, evaluated in growing animals in feedlot-performance tests, decreases enteric $\mathrm{CH}_{4}$ production (g/day) proportionally to the lower DMI.
\end{abstract}

Additional keywords: dry matter intake, performance test, residual feed intake.

Received 2 February 2016, accepted 3 November 2016, published online 23 December 2016

\section{Introduction}

The rising global demand for food stimulates livestock production, but also increases the emission of greenhouse gases. For livestock production systems, nitrous oxide, methane $\left(\mathrm{CH}_{4}\right)$ and carbon dioxide emissions, which are the three main greenhouse gases emitted by the sector, are losses of nitrogen $(\mathrm{N})$, energy and organic matter that undermine efficiency and productivity (Gerber et al. 2013). Enteric $\mathrm{CH}_{4}$ emitted by ruminant animals, as part of their digestive process, is an important greenhouse gas (IPCC 2006). Mitigation of $\mathrm{CH}_{4}$ emission from cattle herds needs to consider feeding systems, which should be adopted without compromising farming costs and animal productivity. Increased animal productivity is a very effective strategy for reducing $\mathrm{CH}_{4}$ emissions per unit of livestock product.
Residual feed intake (RFI) has been used as a selection criterion for beef cattle to increase individual feed efficiency (Grion et al. 2014). Efficient or low-RFI animals have a significant economic advantage since they consume less feed than expected for their weight and rate of gain than do their more inefficient or high-RFI counterparts (Carberry et al. 2012). The selection of low-RFI animals has the potential to significantly reduce feed costs for meat production and the lower consumption can result in less production of enteric $\mathrm{CH}_{4}$ (Hegarty et al. 2007; Fitzsimons et al. 2013). However, Jones et al. (2011) reported that low-RFI animals contribute to reducing $\mathrm{CH}_{4}$ production in grazing systems only when the pasture has a high nutritional value. Freetly and Brown-Brandl (2013) suggested that selection of cattle for increased feed efficiency 
will not necessarily reduce enteric $\mathrm{CH}_{4}$ emission and that $\mathrm{CH}_{4}$ emission may even increase with increasing feed efficiency.

Feed efficiency is usually assessed post-weaning; however, its evaluation in other phases of the production cycle and with different diets is not well established. Studies have shown that crossbred steers fed a grower and finisher diet changed their RFI rankings from one feeding period to another (Durunna et al. 2011), and there is evidence of RFI re-ranking in replacement heifers, using data collected from two feeding trials conducted on a single diet (Durunna et al. 2012).

The objective of the present study was to assess the relationship between RFI evaluated in a feedlot-performance test and that evaluated on pasture, and to determine the effect of feedlot RFI classification on enteric $\mathrm{CH}_{4}$ production in the feedlot and on pasture in growing Nellore beef cattle.

\section{Materials and methods}

The study was approved by the Animal Ethics Committee of Instituto de Zootecnia, Nova Odessa, SP, Brazil, and was conducted in accordance with Guidelines for Animal Welfare and Humane Slaughter (São Paulo State, Law Number 11.977). The study was conducted at Centro APTA Bovinos de Corte, Instituto de Zootecnia, Sertãozinho, São Paulo, Brazil. The climate of the region is tropical humid, with an average annual temperature and rainfall of $24^{\circ} \mathrm{C}$ and $1312 \mathrm{~mm}$ respectively. The experiment included 73 Nellore cattle born in 2011, which were subjected to performance testing in the feedlot (June to November 2012) and on pasture (January to April 2013). Enteric $\mathrm{CH}_{4}$ production was measured in a sample of these animals $(n=47)$.

\section{RFI in the feedlot}

Seventy-three animals (12 males and 13 females with low RFI; 12 males and 12 females with medium RFI; and 12 males and 12 females with high RFI) were sampled from 108 uncastrated males (starting at $272 \pm 22$ days of age and $242 \pm 39 \mathrm{~kg}$ of bodyweight (BW)) and 51 females (starting at $324 \pm 25$ days of age and $259 \pm 29 \mathrm{~kg}$ of $\mathrm{BW}$ ) subjected to a feedlot-performance test and classified within sex as low RFI $($ RFI $<-0.5$ standard deviation (s.d.) below the mean), medium RFI (RFI \pm 0.5 s.d. below and above the mean) and high RFI (RFI $>0.5 \mathrm{~s}$.d. above the mean). The s.d. of RFI was $0.741 \mathrm{~kg}$ and $0.437 \mathrm{~kg}$ for males and females respectively. Males remained in the test for 91 days and females for 86 days. The animals were distributed randomly to the facilities. Eighty-five males were housed in collective pens (only males) equipped with 10 feeders of the GrowSafe ${ }^{\circledR}$ automatic feeding system (GrowSafe Systems, Airdrie, Alberta, Canada), and 23 males and all females were housed in individual pens (two facilities), with ad libitum access to water and ration.

The diet in the performance tests consisted of corn silage, Brachiaria brizantha cv. Marandu, hay and concentrate containing ground corn, soybean meal, urea, mineral salt and ammonium sulfate (Table 1) and was offered twice a day (0800 hours and 1500 hours). Diet samples were collected at intervals of 28 days for the determination of dry matter (DM). In the individual pens, daily intake was calculated as the difference between the amount of feed offered and leftovers. In the collective
Table 1. Percentage of ingredients and chemical composition of the diets used in the feedlot-and pasture-performance tests

$\mathrm{DM}$, dry matter; OM, organic matter; $\mathrm{CP}$, crude protein; NDIN, neutral detergent insoluble nitrogen; ADIN, acid detergent insoluble nitrogen; NDF, neutral detergent fibre; apNDF, NDF corrected for ash and protein; $\mathrm{ADF}$, acid detergent fibre; ADL, acid detergent lignin; iNDF, indigestible NDF; TDN, total digestible nutrients; GE, gross energy; ME, metabolisable energy

\begin{tabular}{|c|c|c|c|}
\hline \multirow[t]{2}{*}{ Ingredient $(\% \mathrm{DM})$} & \multirow{2}{*}{$\begin{array}{c}\text { Feedlot } \\
\text { Whole diet }\end{array}$} & \multicolumn{2}{|c|}{ Pasture } \\
\hline & & Forage & Supplement \\
\hline Corn silage & 53.6 & - & - \\
\hline Ground corn & 21.7 & - & 59.5 \\
\hline Soybean meal & 11.6 & - & - \\
\hline Grass hay & 10.1 & - & - \\
\hline Cottonseed cake & - & - & 25.2 \\
\hline Mineral salt ${ }^{\mathrm{A}}$ & 2.28 & - & 5.11 \\
\hline Ammonium sulfate & 0.072 & - & - \\
\hline Urea & 0.648 & - & 10.2 \\
\hline Forage mass (t/ha) & - & 8.17 & - \\
\hline \multicolumn{4}{|c|}{ Chemical composition of the diet } \\
\hline DM $(\%)$ & 54.4 & 23.5 & 95.4 \\
\hline $\mathrm{OM}(\% \mathrm{DM})$ & 95.3 & 89.9 & 98.3 \\
\hline $\mathrm{CP}(\% \mathrm{DM})$ & 13.9 & 11.2 & 38.9 \\
\hline NDIN (\%DM) & 0.53 & 0.58 & 1.03 \\
\hline ADIN (\%DM) & 0.54 & 0.20 & 0.94 \\
\hline Ether extract (\%DM) & 1.90 & 2.29 & 4.52 \\
\hline NDF (\%DM) & 50.2 & 64.8 & 36.1 \\
\hline apNDF (\%DM) & 45.1 & 57.8 & 31.4 \\
\hline $\mathrm{ADF}(\% \mathrm{DM})$ & 22.9 & 33.2 & 12.3 \\
\hline Cellulose (\%DM) & 19.1 & 30.4 & 7.40 \\
\hline Hemicellulose (\%DM) & 27.2 & 31.0 & 23.8 \\
\hline ADL (\%DM) & 3.80 & 2.21 & 4.93 \\
\hline iNDF (\%DM) & 13.8 & 16.9 & 6.96 \\
\hline $\operatorname{TDN}(\%)^{\mathrm{B}}$ & 70.2 & 68.3 & 68.6 \\
\hline GE (Mcal/kg) & 4.16 & 4.40 & 3.64 \\
\hline $\operatorname{ME}(\mathrm{Mcal} / \mathrm{kg})^{\mathrm{C}}$ & 2.54 & 2.44 & 2.43 \\
\hline
\end{tabular}

${ }^{\mathrm{A} C o m p o s i t i o n} / \mathrm{kg}$ : phosphorus, $8 \%$; calcium, $15 \%$; sodium, $14.5 \%$; sulfur, $1.2 \%$; nickel, $1.1 \%$; zinc, $0.25 \%$; copper, $0.16 \%$; manganese, $0.16 \%$; cobalt, $0.0011 \%$; iodine, $0.0023 \%$; selenium, $0.0027 \%$, fluoride, $0.08 \%$.

${ }^{\mathrm{B}}$ TDN estimated according to Detmann et al. (2010).

${ }^{\mathrm{C}} \mathrm{ME}$ estimated by digestible energy $\times 0.82$.

pens, feed intake was recorded automatically by the GrowSafe ${ }^{\circledR}$ (GrowSafe Systems, Airdrie, AB, Canada). Feed intake was multiplied by DM content and the DM intake (DMI) of each animal was calculated on the basis of the average of all test days.

The animals were weighed weekly in the morning without fasting (males) or at the beginning and end of the test after a 16-h fast (females). The average daily gain (ADG) of each animal was calculated as the linear regression coefficient of weights on the test days (males) or as the difference between final and initial weights on the test days (females).

Residual feed intake was calculated as the difference between the observed DMI and DMI estimated (eDMI) by the regression of $\mathrm{DMI}$ on $\mathrm{ADG}$ and mid-test metabolic bodyweight $\left(\mathrm{BW}^{0.75}\right)$ for each group tested (sex and facility, $n=4$ ), as follows:

$$
\mathrm{DMI}=\beta_{\mathrm{ADG}} \times \mathrm{ADG}+\beta_{\mathrm{BW}}{ }^{0.75} \times \mathrm{BW}^{0.75}+\varepsilon(\text { i.e. } \mathrm{RFI}),
$$


where $\beta_{\mathrm{ADG}}$ and $\beta_{\mathrm{BW}}{ }^{0.75}$ are regression coefficients of the ADG and $\mathrm{BW}^{0.75}$ respectively, and $\varepsilon$ is the residual of the equation (i.e. RFI). The intercept was non-significant for DMI in each group tested and no intercept term was fitted; therefore, $R^{2}$ was not corrected for the mean.

The equations were as follows: $\mathrm{eDMI}=\alpha+1.170( \pm 0.504) \times$ $\mathrm{ADG}+0.070( \pm 0.009) \times \mathrm{BW}^{0.75}\left(R^{2}=0.997\right)$ and $\mathrm{eDMI}=\alpha+$ $1.963( \pm 0.609) \times \mathrm{ADG}+0.063( \pm 0.010) \times \mathrm{BW}^{0.75}\left(R^{2}=0.986\right)$ for males tested in individual and collective pens respectively, and $\mathrm{eDMI}=\alpha+1.843( \pm 0.805) \times \mathrm{ADG}+0.076( \pm 0.012) \times$ $\mathrm{BW}^{0.75}\left(R^{2}=0.996\right)$ and $\mathrm{eDMI}=\alpha+1.463( \pm 0.529) \times \mathrm{ADG}+$ $0.081( \pm 0.007) \times \mathrm{BW}^{0.75}\left(R^{2}=0.997\right)$ for females tested in two facilities with individual pens respectively. In the equations, $\alpha$ is the mean DMI of each group tested.

\section{RFI on pasture}

The 73 animals classified regarding RFI in the feedlotperformance test remained for 78 days (males) and 85 days (females) on pasture after an adaptation period of 28 days. Male animals $(n=36)$ were allocated to nine paddocks of 2 ha (3 paddocks/RFI class; 4 animals/paddock). Female animals $(n=37)$ were allocated to nine paddocks of 1 ha (3 paddocks/ RFI class; 4 animals/paddock, except for one paddock with 5 animals). The pasture consisted of Brachiaria brizantha (Hochst. ex A.Rich.) Stapf cv. Marandu, and the paddocks were equipped with collective feeders for the supply of supplement, drinkers and a covered area of $36 \mathrm{~m}^{2}$.

The grazing method was continuous put-and-take stocking (Allen et al. 2011), and the grazing heights were $30 \mathrm{~cm}$. Nellore animals of the same age, BW and sex were used. Forage quality was evaluated every 28 days by using a hand-plucked technique designed to simulate removal of representative forage (Sollenberger and Cherney 1995). Forage mass was measured every 28 days using two samples collected at ground level by using metal squares $\left(1 \mathrm{~m}^{2}\right)$ from the sites at medium height per paddock. A multiple supplement was offered daily to the animals $(0.5 \mathrm{~kg} /$ animal.day), which consisted of ground corn, cottonseed cake, soybean meal, urea and mineral salt (Table 1). The supplement was formulated to meet the nutritional requirements of male and female Nellore animals for an ADG of $0.8 \mathrm{~kg} /$ day.

Faecal output was estimated using $\mathrm{Cr}_{2} \mathrm{O}_{3}$ as the external marker and $\mathrm{TiO}_{2}$ (Titgemeyer et al. 2001) to estimate individual-supplement intake, both at $10 \mathrm{~g} /$ animal.day, for 9 days. Days 1-7 were used for adaptation and faecal samples were collected from Day 8 to Day 10 at previously defined time points (1500 hours, 1100 hours and 0700 hours). $\mathrm{Cr}_{2} \mathrm{O}_{3}$ was stored in paper cartridges and introduced directly into the oesophagus of the animals at 1200 hours with the aid of a polyvinyl chloride applicator, while $\mathrm{TiO}_{2}$ was homogenised into the supplement. Samples of faeces corresponding to the different collection times composed a sample for each animal. DMI was obtained with the equation proposed by Detmann et al. (2001) using indigestible neutral detergent fibre (iNDF) as the internal marker. The apparent DM digestibility coefficients of pasture-fed animals were calculated as described by Berchielli et al. (2011).
The animals were weighed at intervals of 15 days without previous fasting. The ADG of each animal was calculated as the linear regression coefficient of weights on the test days, and RFI was again calculated as the difference between the observed mean DMI and eDMI with the regression equation of DMI on $\mathrm{ADG}$ and $\mathrm{BW}^{0.75}$ within sex. The intercept was non-significant for DMI. The equations were as follows: eDMI $=\alpha+0.154$ $( \pm 0.910) \times \mathrm{ADG}+0.077( \pm 0.005) \times \mathrm{BW}^{0.75}$ for males, and $\mathrm{eDMI}=\alpha+0.962( \pm 1.684) \times \mathrm{ADG}+0.051( \pm 0.008) \times \mathrm{BW}^{0.75}$ for females, where $\alpha$ is the mean DMI of each sex. No intercept term was used and $R^{2}(0.52)$ was, therefore, not corrected for the mean.

\section{Enteric $\mathrm{CH}_{4}$ production}

After the feedlot-performance test, enteric $\mathrm{CH}_{4}$ production was measured in low-RFI $(n=25)$ and high-RFI $(n=22)$ animals after a 14-day period of adaptation to the collection devices. Faecal samples were collected once a day for three consecutive days and faecal DM excretion of the animals was estimated using iNDF as the internal marker (Cochran et al. 1986). The apparent DM digestibility of the animals in the feedlot performance test was calculated as described by Cochran and Galyean (1994).

Enteric $\mathrm{CH}_{4}$ production on pasture was determined after adaptation of the animals for 28 days. $\mathrm{CH}_{4}$ production was measured by the $\mathrm{SF}_{6}$ tracer-gas technique as described by Johnson and Johnson (1995). Expired and eructated gas samples were stored in collection canisters and replaced at intervals of $24 \mathrm{~h}$ over six consecutive days (continuous sampling for $144 \mathrm{~h}$ ), for a total of six canisters per animal. To correct for atmospheric $\mathrm{CH}_{4}$ concentrations, ambient air samples were collected with two collection canisters per day (basal). At the end of the sampling period, $\mathrm{SF}_{6}$ and $\mathrm{CH}_{4}$ concentrations were determined with an HP6890 gas chromatograph (Agilent, San Jose, CA, USA). The emission of $\mathrm{CH}_{4}$ by the animal was calculated in relation to the known rate of $\mathrm{SF}_{6}$ release in the rumen, subtracting basal $\mathrm{CH}_{4}$ concentrations (Westberg et al. 1998) as follows:

$$
\mathrm{Q}_{\mathrm{CH}_{4}}=\mathrm{Q}_{\mathrm{SF}_{6}}\left(\left[\mathrm{CH}_{4}\right]_{\mathrm{y}}-\left[\mathrm{CH}_{4}\right]_{\mathrm{b}}\right) /\left[\mathrm{SF}_{6}\right],
$$

where $Q_{\mathrm{CH}_{4}}=$ emission rate of $\mathrm{CH}_{4}$ by the animal; $Q_{S_{6}}=$ known emission rate of $\mathrm{SF}_{6} ;\left[\mathrm{CH}_{4}\right]_{y}=\mathrm{CH}_{4}$ concentration in the canister; $\left[\mathrm{CH}_{4}\right]_{b}=$ basal $\mathrm{CH}_{4}$ concentration, and $\left[\mathrm{SF}_{6}\right]=\mathrm{SF}_{6}$ concentration in the canister.

\section{Chemical analyses}

The forage samples, silage samples, concentrate ingredients, leftovers and faecal samples were weighed and dried in a forced-ventilation oven at $60 \pm 5^{\circ} \mathrm{C}$ for $72 \mathrm{~h}$, ground in a Willey mill (Thomas Scientific, Swedesboro, NJ, USA) to pass through a 1-mm screen, and analysed for the determination of DM (Method 934.01), mineral matter (Method 942.05) and ether extract (Method 920.39) according to the AOAC (1990). Crude energy was determined with an automated IKA ${ }^{\circledR}$ calorimeter Model 2000 (IKA WORKS Inc., Staufen, Breisgau, Germany). N was determined by the Dumas method (Etheridge et al. 1998), which is based on the release of $\mathrm{N}$ by combustion at high temperature in pure oxygen in a LECO FP-528 nitrogen analyser (LECO Corporation, St Joseph, MI, USA). NDF and 
Table 2. Performance and efficiency traits of Nellore cattle classified for residual feed intake (RFI) in the feedlot- and pasture-performance tests Means in the same row followed by different lowercase letters differ significantly $(P<0.05)$. BW ${ }^{0.75}$, metabolic bodyweight; DMI, dry-matter intake; ADG, average daily gain; RFI, residual-feed intake

\begin{tabular}{|c|c|c|c|c|c|c|c|c|c|c|}
\hline \multirow[t]{2}{*}{ Trait } & \multicolumn{3}{|c|}{$\begin{array}{c}\text { Feedlot } \\
\text { RFI }\end{array}$} & \multirow[t]{2}{*}{ s.e.m. } & \multirow[t]{2}{*}{$P$-value } & \multicolumn{3}{|c|}{$\begin{array}{c}\text { Pasture } \\
\text { RFI }\end{array}$} & \multirow[t]{2}{*}{ s.e.m. } & \multirow[t]{2}{*}{$P$-value } \\
\hline & $\begin{array}{c}\text { Low } \\
(n=25)\end{array}$ & $\begin{array}{l}\text { Medium } \\
(n=24)\end{array}$ & $\begin{array}{c}\text { High } \\
(n=24)\end{array}$ & & & $\begin{array}{c}\text { Low } \\
(n=25)\end{array}$ & $\begin{array}{l}\text { Medium } \\
(n=24)\end{array}$ & $\begin{array}{c}\text { High } \\
(n=24)\end{array}$ & & \\
\hline Age (day) & 295 & 302 & 295 & 4.84 & 0.508 & 470 & 477 & 470 & 4.84 & 0.510 \\
\hline Initial BW (kg) & 246 & 258 & 244 & 6.68 & 0.329 & 377 & 374 & 369 & 6.72 & 0.734 \\
\hline Final BW (kg) & 343 & 351 & 341 & 7.52 & 0.619 & 402 & 399 & 391 & 6.36 & 0.450 \\
\hline $\mathrm{BW}^{0.75}(\mathrm{~kg})$ & 71.2 & 73.2 & 70.8 & 1.31 & 0.402 & 88.5 & 88.0 & 86.8 & 1.09 & 0.558 \\
\hline DMI (kg/day) & $6.31 \mathrm{c}$ & $7.12 b$ & $7.86 \mathrm{a}$ & 0.148 & $<0.001$ & 6.07 & 5.88 & 5.85 & 0.262 & 0.808 \\
\hline ADG (kg/day) & 1.11 & 1.11 & 1.12 & 0.032 & 0.990 & 0.463 & 0.467 & 0.411 & 0.037 & 0.492 \\
\hline RFI (kg DM/day) & $-0.683 \mathrm{c}$ & $-0.022 b$ & $0.787 \mathrm{a}$ & 0.058 & $<0.001$ & 0.076 & -0.078 & -0.003 & 0.251 & 0.910 \\
\hline
\end{tabular}

ADF analyses were based on procedures described by Mertens (2002), both adapted to the Ankom200 Fibre Analyzer (Ankom Technology, Fairport, NY, USA) and revised to ash and protein, according to Licitra et al. (1996).

The digestion assays for the recovery of $\mathrm{TiO}_{2}$ from faecal samples were performed as described by Myers et al. (2004), and for the recovery of $\mathrm{Cr}_{2} \mathrm{O}_{3}$ by the wet method as described by Kimura and Miller (1957). The content of iNDF in the feed, leftover and faecal samples was determined after in situ incubation for $288 \mathrm{~h}$ (Casali et al. 2008).

\section{Statistical analyses}

Least-square means were calculated to compare the variables between RFI classes (low, medium and high, and only low and high for the period of measurement of enteric $\mathrm{CH}_{4}$ production) using the general linear model procedure (SAS Institute Inc., Cary, NC, USA). The statistical model included the effects of RFI class, sex (male or female), and the interaction between RFI class and sex. Means were compared by the Tukey test and significance was considered when $P<0.05$. Pearson correlations were estimated for $\mathrm{BW}, \mathrm{BW}^{0.75}$, DMI, ADG and RFI obtained in the feedlot-and pasture-performance tests, and for BW, DMI, NDFI, GEI, DM digestibility (DMD), NDF digestibility (NDFD), gross-energy digestibility (GED) and $\mathrm{CH}_{4}$ (g/day) determined during the period of $\mathrm{CH}_{4}$ measurement in the feedlot and on pasture. Pearson correlations were also estimated between RFI and $\mathrm{CH}_{4}, \mathrm{DMD}$ and $\mathrm{CH}_{4}$, and $\mathrm{RFI}$ and DMD within each testing environment.

\section{Results}

\section{Residual feed intake}

In the feedlot- and pasture-performance tests, no significant differences in the initial $\mathrm{BW}$, final $\mathrm{BW}, \mathrm{BW}^{0.75}$ or $\mathrm{ADG}$ were observed among animals classified as low, medium and high RFI in the feedlot test (Table 2). In the feedlot-performance test, DMI of low-RFI animals was $9.4 \%$ and $19.7 \%$ lower $(P<0.05)$ than that of medium- and high-RFI animals respectively. The mean RFI was $-0.683,-0.022$ and $0.787 \mathrm{~kg} \mathrm{DM}$ /day for the low-, medium- and high-RFI class, with a mean difference in RFI of $1.47 \mathrm{~kg} \mathrm{DM} /$ day between greater- and lower-efficient animals. On pasture, there was no difference in DMI and, consequently, in RFI among animals classified as low-, medium- and high-feedlot
RFI. The effect of sex was significant for age, initial and final $\mathrm{BW}, \mathrm{BW}^{0.75}$, and DMI in feedlot and pasture, and the interaction RFI class $\times$ sex was significant only for DMI and RFI obtained in the feedlot test.

Pearson correlations between DMI, ADG and RFI obtained in the feedlot and on pasture were low, except for $\mathrm{BW}$ and $\mathrm{BW}^{0.75}$, which showed a significant $(P<0.001)$ correlation of medium to high magnitude (Table 3 ).

\section{$\mathrm{CH}_{4}$ production}

During the period of enteric $\mathrm{CH}_{4}$ measurement in the feedlot or pasture, no significant difference was observed in $\mathrm{BW}$ or $\mathrm{BW}^{0.75}$ between animals classified as low and those classified as high RFI (feedlot-performance test; Table 4). Faecal excretion of low-RFI animals was $9.5 \%$ and $12.7 \%$ lower than that of high-RFI animals during the period of enteric $\mathrm{CH}_{4}$ measurement in the feedlot and on pasture respectively. Low-RFI animals had lower DMI, NDFI and GEI than high-RFI animals during both periods of enteric $\mathrm{CH}_{4}$ measurement $(P<0.05)$. Low-RFI animals exhibited higher DMD and NDFD than did high-RFI animals during the period of enteric $\mathrm{CH}_{4}$ measurement in the feedlot, but a similar GED $(P>0.05)$. In contrast, no significant difference in DMD, NDFD or GED was observed between low- and high-RFI animals during the period of measurement on pasture.

The production of enteric $\mathrm{CH}_{4}$, in both periods of measurement, expressed as g/day and $\mathrm{kg} /$ year did not differ between low- and high-RFI animals $(P>0.05)$, while methane production expressed as $\mathrm{g} / \mathrm{BW}$ and $\mathrm{g} / \mathrm{BW}^{0.75}$ differed between low- and high-RFI animals during the feedlot period $(P<0.05)$. The production of $\mathrm{CH}_{4}$ expressed as $\mathrm{g} / \mathrm{kg}$ DMI, $\mathrm{g} / \mathrm{kg}$ NDFI and $\%$ GEI did not differ between low- and high-RFI animal during the feedlot period $(P>0.05)$, but significant differences were observed between these animals during the period of enteric $\mathrm{CH}_{4}$ measurement on pasture. The effect of sex was significant for $\mathrm{BW}, \mathrm{CH}_{4}$ and for the variables related to DMI, and the interaction between RFI class $\times$ sex was significant only for DMI-related variables.

Low correlations were estimated between the traits (DMI, NDFI, GEI, DMD, NDFD and GED) obtained during the period of $\mathrm{CH}_{4}$ measurement in the feedlot and on pasture $(n=47)$. However, a moderate correlation (0.411) was observed in enteric $\mathrm{CH}_{4}$ production ( $\mathrm{g} /$ day) between the feedlot and on pasture and a 
high correlation (0.883) was observed in BW (Table 3). The correlations between RFI vs $\mathrm{CH}_{4}(0.068$ and $-0.117 ; P=0.652$ and $P=0.433)$ and DMD vs $\mathrm{CH}_{4}(-0.176$ and $0.010 ; P=0.237$ and $P=0.947)$ were not significant both in the feedlot and on pasture respectively. A moderate correlation was observed between RFI vs DMD ( -0.410 and $0.381, P=0.004$ and $P=0.008$, in the feedlot and on pasture respectively; Fig. 1) and RFI vs NDFD $(-0.366, P=0.011$, in the feedlot).

\section{Discussion}

The ranking and selection of animals that will remain efficient during different growth phases and in different production systems, while keeping enteric $\mathrm{CH}_{4}$ emissions low, are important challenges for beef-cattle producers worldwide. Although a considerable proportion of the global beef cattle herd is raised on pasture, available studies are restricted to the assessment of RFI in feedlot animals, without subsequent reranking on pasture. Here, we address this limitation of current knowledge, taking into consideration the effects on enteric $\mathrm{CH}_{4}$ emissions.

Average daily gain did not differ among the RFI classes (Table 2), since RFI is an efficiency measure that is independent of growth rate or animal performance (Koch et al. 1963). As also reported in recent studies (Sobrinho et al. 2011; Fitzsimons et al. 2013), lower DMI (kg/day) was attributed to low-RFI animals in the feedlot (Table 2). On pasture, DMI was similar in low-, medium- and high-feedlot RFI animals. Studies also reported similar DMI on pasture for low- and high-RFI animals previously evaluated in a post-weaning feedlot-performance test (Herd et al.1998) or on pasture (Jones et al. 2011). These results can be probably due to intrinsic errors of the methods used to estimate the DMI of animals on pasture, impairing a very accurate individual estimate of DMI for the calculation of RFI, although the average DMI estimated

Table 3. Pearson's correlation coefficient between traits obtained in the feedlot and those obtained on pasture

$\mathrm{BW}^{0.75}$, metabolic bodyweight; DMI, dry-matter intake; ADG, average daily gain; RFI, residual-feed intake; NDFI, neutral detergent-fibre intake; GEI, gross-energy intake; DMD, dry-matter digestibility; NDFD, neutral detergent-fibre digestibility; GED, gross-energy digestibility; $\mathrm{CH}_{4}$ (g/day)

\begin{tabular}{lcr}
\hline Trait & Correlation coefficient & $P$-value \\
\hline & Performance-test period $(n=73)$ & \\
BW & 0.731 & $<0.001$ \\
BW ${ }^{0.75}$ & 0.607 & $<0.001$ \\
DMI & -0.097 & 0.414 \\
ADG & 0.113 & 0.340 \\
RFI & -0.033 & 0.783 \\
& Measurement of enteric CH $_{4}$ period $(n=47)$ & \\
BW & 0.880 & $<0.001$ \\
DMI & 0.108 & 0.472 \\
NDFI & 0.077 & 0.608 \\
GEI & 0.136 & 0.362 \\
DMD & 0.171 & 0.249 \\
NDFD & 0.187 & 0.208 \\
GED & 0.160 & 0.282 \\
CH & 0.411 & 0.004 \\
\hline
\end{tabular}

on pasture is consistent with that of grazing animals (Canesin et al. 2014). However, using the same method (n-alkanes) as used by Herd et al. (1998) for the estimation of DMI on pasture, Manafiazar et al. (2015) observed that beef heifers classified as low RFI during the pos-tweaning feedlot period had a lower DMI as heifers grazing pasture than did their highRFI herd mates.

The correlations showed changes in RFI calculated in the feedlot and then on pasture, when the animals were already in another growth phase, as shown in Table 3. The low or null correlations between the two performance tests indicated that most animals were reranked and that the feed efficiency identified in animals may not correspond to the efficiency of these animals when subsequently tested on pasture.

Some studies have evaluated the feed efficiency of animals during different periods and using different diets and, indeed, observed low to medium rank correlations between animals (Durunna et al. 2011, 2012; Magnani et al. 2013b), implying that the period of evaluation and diet affect the RFI of animals.

Low to medium correlations between ADG obtained in different tests are expected (Mercadante et al. 2015), since this trait is the most variable among the three RFI components (Wang et al. 2006). However, the low correlations close to zero between DMI and RFI obtained in the feedlot- and pasture-performance tests were not expected (Durunna et al. 2011, 2012; Magnani et al. 2013b; Mercadante et al. 2015). Despite advances in the experimental and analytical procedures over time, the estimation of feed intake in pasture-raised animals continues to be costly and of low accuracy.

During the period of enteric $\mathrm{CH}_{4}$ measurement (Table 4), lower NDFI and GEI (kcal/day) were observed in low-RFI animals than in high-RFI animals because of the lower DMI, both in the feedlot and on pasture. In feedlot, higher DMD and NDFD were measured in low-RFI animals (Table 4) and a negative relationships between RFI and DMD (Fig. 1) and NDFD of the diet during the period of enteric $\mathrm{CH}_{4}$ measurement were observed. These differences among RFI classes are consistent with the results of Nkrumah et al. (2006) and Magnani et al.

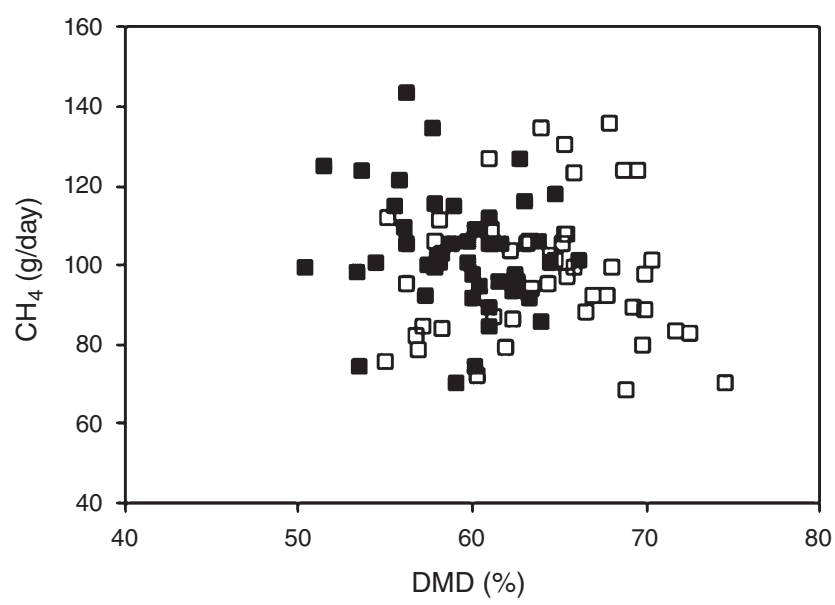

Fig. 1. Enteric methane $\left(\mathrm{CH}_{4}\right)$ production and dry matter digestibility (DMD) obtained in the feedlot (solid symbols) and on pasture (open symbols). 
Table 4. Enteric methane production during the feedlot and pasture periods of Nellore cattle classified as low and high residual feed intake (RFI) in the feedlot

$\mathrm{BW}^{0.75}$, metabolic bodyweight; FE, faecal excretion; DMI, dry-matter intake; NDFI, neutral detergent-fibre intake; GEI, grossenergy intake; DMD, dry-matter digestibility; NDFD, neutral detergent-fibre digestibility; GED, gross-energy digestibility

\begin{tabular}{|c|c|c|c|c|c|c|c|c|}
\hline & \multicolumn{2}{|c|}{$\begin{array}{c}\text { Feedlot } \\
\text { RFI }\end{array}$} & \multirow[t]{2}{*}{ s.e.m. } & \multirow[t]{2}{*}{$P$-value } & \multicolumn{2}{|c|}{$\begin{array}{c}\text { Pasture } \\
\text { RFI }\end{array}$} & \multirow[t]{2}{*}{ s.e.m. } & \multirow[t]{2}{*}{$P$-value } \\
\hline & Low $(n=25)$ & High $(n=22)$ & & & Low $(n=25)$ & High $(n=22)$ & & \\
\hline \multicolumn{9}{|c|}{ Trait $^{\mathrm{A}}$} \\
\hline BW (kg) & 357 & 355 & 7.71 & 0.852 & 377 & 368 & 7.25 & 0.356 \\
\hline $\mathrm{BW}^{0.75}(\mathrm{~kg})$ & 82.0 & 81.6 & 1.33 & 0.832 & 85.5 & 83.9 & 1.24 & 0.365 \\
\hline FE (kg/day) & 3.92 & 4.33 & 0.085 & 0.001 & 2.20 & 2.52 & 0.104 & 0.036 \\
\hline DMI (kg/day) & 8.57 & 9.43 & 0.202 & 0.004 & 5.98 & 7.42 & 0.362 & 0.007 \\
\hline NDFI (kg/day) & 4.34 & 4.79 & 0.105 & 0.005 & 3.63 & 4.43 & 0.214 & 0.012 \\
\hline GEI (kcal/day) & 35.8 & 39.3 & 0.840 & 0.005 & 22.2 & 27.2 & 1.31 & 0.009 \\
\hline DMD (\%) & 60.9 & 57.0 & 0.564 & $<0.001$ & 63.1 & 65.5 & 1.04 & 0.116 \\
\hline NDFD (\%) & 57.5 & 54.6 & 0.592 & 0.001 & 62.7 & 63.4 & 1.11 & 0.651 \\
\hline GED (\%) & 59.6 & 57.0 & 1.25 & 0.150 & 62.5 & 64.9 & 1.21 & 0.182 \\
\hline \multicolumn{9}{|c|}{ Enteric $\mathrm{CH}_{4}$ production } \\
\hline $\mathrm{CH}_{4}$ (g/day) & 101 & 107 & 2.75 & 0.152 & 101 & 95.9 & 3.26 & 0.279 \\
\hline $\mathrm{CH}_{4}(\mathrm{~kg} /$ year $)$ & 37.0 & 39.1 & 1.01 & 0.152 & 36.9 & 35.0 & 1.19 & 0.279 \\
\hline $\mathrm{CH}_{4}(\mathrm{~kg} / \mathrm{BW})$ & 0.28 & 0.30 & 0.007 & 0.053 & 0.27 & 0.26 & 0.008 & 0.627 \\
\hline $\mathrm{CH}_{4}\left(\mathrm{~g} / \mathrm{kg} \mathrm{BW} \mathrm{BW}^{0.75}\right)$ & 1.23 & 1.32 & 0.029 & 0.054 & 1.18 & 1.15 & 0.36 & 0.510 \\
\hline $\mathrm{CH}_{4}(\mathrm{~g} / \mathrm{kg} \mathrm{DMI})$ & 11.9 & 11.4 & 0.254 & 0.166 & 17.6 & 13.7 & 0.786 & 0.001 \\
\hline $\mathrm{CH}_{4}(\mathrm{~g} / \mathrm{kg}$ NDFI $)$ & 23.4 & 22.5 & 0.492 & 0.187 & 29.1 & 22.9 & 1.28 & 0.001 \\
\hline $\mathrm{CH}_{4}(\% \mathrm{GEI})$ & 2.85 & 2.71 & 0.062 & 0.120 & 4.85 & 3.71 & 0.206 & $<0.001$ \\
\hline
\end{tabular}

${ }^{\mathrm{A}}$ Traits determined during the period of measurement of enteric $\mathrm{CH}_{4}$ in the feedlot and on pasture.

(2013a), who observed greater DMD and NDFD in low-RFI animals. On feedlot, the results of the present study supported the hypothesis that the greater efficiency in low-RFI cattle could be partially explained by an enhanced capacity to digest ingested feed (Richardson and Herd 2004). In contrast, no difference in nutrient digestibility among the RFI classes was observed when the animals were measured on pasture. The variation in diet digestibility between animals is due to factors such as the mechanism of digestion and absorption, rumen retention time and ingestive behaviour (Russell and Gahr 2000). On pasture, the animals have $40.1 \%$ more feeding time and $\sim 14.2 \%$ more time on rumination activity than on feedlot, and the greatest chewing stimulation promotes increased saliva production, which improves the conditions of ruminal $\mathrm{pH}$ and development of microbes responsible for greater digestion of fibre (Segabinazzi et al. 2014). This fact corroborates with the results of Cota et al. (2014), who observed a lower nutrient intake and greater digestibility in Nellore cattle on pasture than on feedlot.

In the present study, enteric $\mathrm{CH}_{4}$ production $(\mathrm{g} / \mathrm{day}$ and $\mathrm{kg} /$ year) measured in both periods was similar in low- and high-RFI animals. Since animals that are more efficient have a lower DMI adjusted for $\mathrm{ADG}$ and $\mathrm{BW}^{0.75}$, the hypothesis can be raised that these animals produce smaller amounts of enteric $\mathrm{CH}_{4}$ than do their less efficient counterparts. Indeed, some studies have shown that more efficient animals produce less enteric $\mathrm{CH}_{4}$ than less efficient animals, especially when these animals are fed a highconcentrate diet (Hegarty et al. 2007). However, the results reported by Freetly and Brown-Brandl (2013) and Mercadante et al. (2015) did not support the hypothesis that an increase in feed efficiency decreases $\mathrm{CH}_{4}$ production. The authors, respectively, found a positive correlation between $\mathrm{ADG}$ : DMI and $\mathrm{CH}_{4}$ and similar $\mathrm{CH}_{4}$ production in low- and high-RFI animals receiving a diet that contained more than $50 \%$ roughage. Freetly and BrownBrandl (2013) suggested the increase in $\mathrm{CH}_{4}$ production rates with increasing feed efficiency (ADG : DMI) to be the result of higher feed fermentation, increasing the availability of nutrients and enteric $\mathrm{CH}_{4}$ production. Similarly, Jones et al. (2011) found no difference in enteric $\mathrm{CH}_{4}$ production $\left(\mathrm{g} / \mathrm{kg} \mathrm{BW} ; \mathrm{g} / \mathrm{kg} \mathrm{BW}^{0.75}\right.$ ) of cows with different RFI maintained on pasture. According to de Haas et al. (2011), the limited evidence available indicates that an increase in feed efficiency is partially or completely related to a higher level of fermentation and digestion of the ingested feed and, consequently, to higher enteric $\mathrm{CH}_{4}$ production per unit feed and greater \%GEI lost as $\mathrm{CH}_{4}$. These results support the higher digestibility of DM and NDF (in the feedlot), similar $\mathrm{CH}_{4}$ production expressed as g/day (in the feedlot and on pasture), and higher $\mathrm{CH}_{4}$ production expressed as $\mathrm{g} / \mathrm{kg}$ DMI, $\mathrm{g} / \mathrm{kg}$ NDFI and \%GEI (on pasture) of low-RFI animals when compared with high-RFI animals. During the period of enteric $\mathrm{CH}_{4}$ measurement on pasture, the reduced rumen retention time in high-RFI animals, associated with a higher feed intake, probably tends to lower $\mathrm{CH}_{4}$ yield per unit DMI.

The production of $\mathrm{CH}_{4}$ expressed as $\mathrm{g} /$ day observed in the present study was lower than the $147 \mathrm{~g} \mathrm{CH}_{4} /$ day estimated by Fiorentini et al. (2014) for Nellore cattle fed a high-roughage diet ( $60 \%$ corn silage), and the value reported by the IPCC (2006) which estimated a mean emission of $49 \mathrm{~kg} \mathrm{CH}_{4} /$ year for young cattle $(230 \mathrm{~kg} \mathrm{BW})$ in Latin America. The percentage of gross energy lost as enteric $\mathrm{CH}_{4}$ (\%GEI) was lower than the values reported by Fiorentini et al. $(2014 ; 4.81 \%)$ and those observed for continental crossbred steers fed corn silage-based diets 
(7.3-8.4\%; McGeough et al. 2010). Importantly, the values in the present study were lower than those estimated by the models developed by IPCC (2006) of $6.5 \%$ for cattle raised under tropical conditions.

\section{Conclusions}

In conclusion, it is not possible to affirm that animals with a lower DMI and the same performance emit less enteric $\mathrm{CH}_{4}$ than do animals with a higher intake. Under the conditions of the present study, there is evidence of re-ranking of animals for RFI tested in the feedlot after weaning and, subsequently, on pasture.

\section{Acknowledgements}

The authors thank Conselho Nacional de Desenvolvimento Científico e Tecnológico (CNPq, Proc. 562783/2010-5) and Fundação de Amparo à Pesquisa do Estado de São Paulo (FAPESP, Proc. 2010/52201-1) for financial support, and Coordenação de Aperfeiçoamento de Pessoal de Nível Superior (CAPES) for the scholarship granted.

\section{References}

Allen VG, Batello C, Berretta EJ, Hodgson J, Kothmann M, Li X, McIvor J, Milne J, Morris C, Peeters A, Sanderson M (2011) An international terminology for grazing lands and grazing animals. Grass and Forage Science 66, 2-28. doi:10.1111/j.1365-2494.2010.00780.x

Association of Official Analytical Chemists (AOAC) (1990) 'Official methods of analysis.' 15th edn (Ed. K Helrich) (AOAC: Arlington, VA)

Berchielli TT, Vega Garcia A, Oliveira SG (2011) Principais técnicas de avaliação aplicadas em estudo de nutrição. In 'Nutrição de ruminantes'. (Eds TT Berchielli, AV Pires, SG Oliveira) pp. 565-600. (Funep: Jaboticabal, Brasil) [In Brazilian]

Canesin RC, Berchielli TT, Vega A, Reis RA, Messana JD, Baldi F, Páscoa AG (2014) Reducing supplementation frequency for Nellore beef steers grazing tropical pastures. Scientia Agrícola 71, 105-113. doi:10.1590/ S0103-90162014000200003

Carberry CA, Kenny DA, Han S, McCabe MS, Waters SM (2012) Effect of phenotypic residual feed intake and dietary forage content on the rumen microbial community of beef cattle. Applied and Environmental Microbiology 78, 4949-4958. doi:10.1128/AEM.07759-11

Casali AO, Detmann E, Valadares Filho SC (2008) Influência do tempo de incubação e do tamanho de partículas sobre os teores de compostos indigestíveis em alimentos e fezes bovinas obtidos por procedimentos in situ. Revista Brasileira de Zootecnia 37, 335-342. [In Brazilian] doi:10.1590/S1516-35982008000200021

Cochran RC, Galyean ML (1994) Measurement of in vivo forage digestion by ruminants. In 'Forage quality, evaluation and utilization'. (Ed. GC Fahey Jr) pp. 613-643. (American Society of Agronomy: Madison, WI)

Cochran RC, Adams DC, Wallace JD (1986) Predicting digestibility of different diets with internal markers: evaluation of four potential markers. Journal of Animal Science 63, 1476-1483. doi:10.2527/ jas $1986.6351476 x$

Cota O, Figueiredo DM, Branco RH, Magnani E, Nascimento CF, Oliveira LF, Mercadante MEZ (2014) Methane emission by Nellore cattle subjected to different nutritional plans. Tropical Animal Health and Production 46, 1229-1234. doi:10.1007/s11250-014-0632-3

de Haas Y, Windig JJ, Calus MPL, Dijkstra J, Haan M, Bannink A, Veerkamp RF (2011) Genetic parameters for predicted methane production and potential for reducing enteric emissions through genomic selection. Journal of Dairy Science 94, 6122-6134. doi:10.3168/jds.2011-4439

Detmann E, Paulino MF, Zervoudakis JT, Valares Filho SC, Euclydes RF, Lana RP, Queiroz DS (2001) Cromo e indicadores internos na determinação do consumo de novilhos mestiços, suplementados, a pasto. Revista Brasileira de Zootecnia 30, 1600-1609. [In Brazilian] doi:10.1590/S1516-35982001000600030

Detmann E, Valadares Filho SC, Paulino MF (2010) Predição do valor energético de dietas para bovinos a partir da composição química dos alimentos. In 'Exigências Nutricionais de Zebuínos Puros e Cruzados: BR-Corte'. (Eds SC Valadares, MI Marcondes, ML Chizzotti, PVR Paulino) pp. 47-64. (UFV: Viçosa, Brasil) [In Brazilian]

Durunna ON, Mujibi FDN, Goonewardene L, Okine EK, Basarab JA, Wang Z, Moore SS (2011) Feed efficiency differences and reranking in beef steers fed grower and finisher diets. Journal of Animal Science 89, 158-167. doi:10.2527/jas.2009-2514

Durunna ON, Colazo MG, Ambrose DJ, McCartney D, Baron VS, Basarab JA (2012) Evidence of residual feed intake reranking in crossbred replacement heifers. Journal of Animal Science 90, 734-741. doi:10.2527/jas.2011-4264

Etheridge RD, Pesti GM, Foster EH (1998) A comparison of nitrogen values obtained utilizing the Kjeldahl nitrogen and Dumas combustion methodologies (Leco CNS 2000) on samples typical of an animal nutrition analytical laboratory. Animal Feed Science and Technology 73, 21-28. doi:10.1016/S0377-8401(98)00136-9

Fiorentini G, Carvalho IPC, Messana JD, Castagnino PS, Berndt A, Canesin RC, Frighetto RTS, Berchielli TT (2014) Effect of lipid sources with different fatty acid profiles on the intake, performance, and methane emissions of feedlot Nellore steers. Journal of Animal Science 92, 1613-1620. doi:10.2527/jas.2013-6868

Fitzsimons C, Kenny DA, Deighton MH, Fahey AG, McGee M (2013) Methane emissions, body composition, and rumen fermentation traits of beef heifers differing in residual feed intake. Journal of Animal Science 91, 5789-5800. doi:10.2527/jas.2013-6956

Freetly HC, Brown-Brandl TM (2013) Enteric methane production from beef cattle that vary in feed efficiency. Journal of Animal Science 91, 4826-4831. doi:10.2527/jas.2011-4781

Gerber PJ, Steinfeld H, Henderson B, Mottet A, Opio C, Dijkman J, Falcucci A, Tempio G (2013) 'Tackling climate change through livestock: a global assessment of emissions and mitigation opportunities.' (FAO: Rome)

Grion AL, Mercadante MEZ, Cyrillo JNSG, Bonilha SMF, Magnani E, Branco RH (2014) Selection for feed efficiency traits and correlated genetic responses in feed intake and weight gain of Nellore cattle. Journal of Animal Science 92, 955-965. doi:10.2527/jas.2013-6682

Hegarty RS, Goopy JP, Herd RM, McCorkell B (2007) Cattle selected for lower residual feed intake have reduced daily methane production. Journal of Animal Science 85, 1479-1486. doi:10.2527/jas.2006-236

Herd RM, Richardson EC, Hegarty RS, Woodgate R, Archer JA, Arthur PF (1998) Pasture intake by high versus low net feed efficient Angus cows. Animal Production in Australia 22, 137-140.

IPCC (2006) '2006 IPCC guidelines for national greenhouse gas inventories. Agriculture, forestry and other land use.' (Eds HS Eggleston, L Buendia, K Miwa, T Ngara, K Tanabe) pp. 10.1-10.89. (Institute for Global Energy Strategies: Hayama, Japan)

Johnson KA, Johnson DE (1995) Methane emissions from cattle. Journal of Animal Science 73, 2483-2492. doi:10.2527/1995.7382483x

Jones FM, Phillips FA, Naylor T, Mercer NB (2011) Methane emissions from grazing Angus beef cows selected for divergent residual feed intake. Animal Feed Science and Technology 166-167, 302-307. doi:10.1016/j. anifeedsci.2011.04.020

Kimura FT, Miller VL (1957) Improved determination of chromic oxide in cow feed and feces. Journal of Agricultural and Food Chemistry 5, 216. doi:10.1021/jf60073a008

Koch RM, Swiger LA, Chambers D, Gregory KE (1963) Efficiency of feed use in beef cattle. Journal of Animal Science 22, 486-494. doi:10.2527 jas1963.222486x

Licitra G, Hernandez TM, Van Soest PJ (1996) Standardization of procedures for nitrogen fractionation of ruminant feeds. Animal Feed Science and Technology 57, 347-358. doi:10.1016/0377-8401(95)00837-3 
Magnani E, Nascimento CF, Branco RH, Bonilha SFM, Ribeiro EG, Mercadante MEZ (2013a) Relações entre consumo alimentar residual, comportamento ingestivo e digestibilidade em novilhas Nelore. Boletim de Indústria Animal 70, 187-194. [In Brazilian] doi:10.17523/bia. v70n2p187

Magnani E, Sakamoto L, Grion AL, Nascimento CF, Bonilha SFM, Mercadante MEZ, Branco RH (2013b) Rank correlation for residual feed intake obtained during growth and finishing stages in Nellore cattle. In 'Proceedings of the 50th annual meeting of Brazilian Society of Animal Science'. (Brazilian Society of Animal Science: Campinas, Brazil)

Manafiazar G, Basarab JA, Baron VS, McKeown L, Doce RR, Swift M, Undi M, Wittenberg K, Ominski K (2015) Effect of post-weaning residual feed intake classification on grazed grass intake and performance in pregnant beef heifers. Canadian Journal of Animal Science 95, 369-381. doi:10.4141/cjas-2014-184

McGeough EJ, O' Kiely P, Foley PA, Hart KJ, Boland TM, Kenny DA (2010) Methane emissions, feed intake, and performance of finishing beef cattle offered maize silages harvested at 4 different stages of maturity. Journal of Animal Science 88, 1479-1491. doi:10.2527/jas.2009-2380

Mercadante MEZ, Caliman APM, Canesin RC, Bonilha SFM, Berndt A, Frighetto RTS, Magnani E, Branco RH (2015) Relationship between residual feed intake and enteric methane emission in Nellore cattle. Revista Brasileira de Zootecnia 44, 255-262. doi:10.1590/S180692902015000700004

Mertens DR (2002) Gravimetric determination of amylase-treated neutral detergent fiber in feeds with refluxing in beakers or crucibles: collaborative study. Journal of AOAC International 85, 1217-1240.

Myers WD, Ludden PA, Nayigihugu V, Hess BW (2004) Technical note: a procedure for the preparation and quantitative analysis of samples for titanium dioxide. Journal of Animal Science 82, 179-183. doi:10.2527/ 2004.821179x

Nkrumah JD, Okine EK, Mathison GW, Schmid K, Li C, Basarab JA, Price MA, Wang Z, Moore SS (2006) Relationships of feedlot feed efficiency, performance, and feeding behavior with metabolic rate, methane production, and energy partitioning in beef cattle. Journal of Animal Science 84, 145-153. doi:10.2527/2006.841145x

Richardson EC, Herd RM(2004) Biological basis for variation in residual feed intake in beef cattle. 2. Synthesis of results following divergent selection. Australian Journal of Agricultural Research 44, 431-440.

Russell RW, Gahr AS (2000) Glucose availability and associated metabolism. In 'Farm animal metabolism and nutrition'. (Ed. JPF D'Mello) pp. 127-147. (CABI Publishing: Edinburgh, UK)

Segabinazzi LR, Menezes LFG, Silva CEK, Martinello C, Boito B, Molinete ML (2014) Diurnal ingestive behavior of Holstein calves reared in different systems: feedlot or pasture. Acta Scientiarum. Animal Science 36, 225-231.

Sobrinho TL, Branco RH, Bonilha SMF, Castilhos AM, Figueiredo LA, Razook AG, Mercadante MEZ (2011) Residual feed intake and relationships with performance of Nellore cattle selected for post weaning weight. Revista Brasileira de Zootecnia 40, 929-937. doi:10.1590/S1516-35982011000400030

Sollenberger LE, Cherney DJR (1995) Evaluating forage production and quality. In 'Forages: the science of grassland agriculture'. (Eds RF Barnes, DA Miller, CJ Nelson) pp. 97-110. (Iowa State University Press: Ames, IA)

Titgemeyer EC, Armendariz CK, Bindel DJ (2001) Evaluation of titanium dioxide as a digestibility marker for cattle. Journal of Animal Science 79, 1059-1063. doi:10.2527/2001.7941059x

Wang Z, Nkrumah JD, Li C, Basarab JA, Goonewardene LA, Okine EK (2006) Test duration for growth, feed intake, and feed efficiency in beef cattle using the GrowSafe System. Journal of Animal Science 84, 2289-2298. doi:10.2527/jas.2005-715

Westberg H, Johnson KA, Cossalman MW, Michal JJA (1998) 'SF6 tracer technique: methane measurement from ruminants.' (Washington State University: Pullman, WA) 